\title{
Preparative studies on the isolation of an enzyme associated with carthamin synthesis in Carthamus tinctorius $\mathbf{L}$.
}

\author{
TAKAO HOMMA. MAKIKO SAWAGUCHI HIROKAZU KAWAI YOSHIYUKI TAKAHASHI KOSHI SAITO*
}

Department of Applied Chemistry. Faculty of Engineering. Tokai University. 1117 Kitakaname. Hiratsuka-shi, Kanagawa-ken 259-12, Japan

(Received: March 2. 1985. Accepted: May 21. 1985)

\begin{abstract}
Preliminary operations for the isolation of an enzyme associated with cathamin synthesis (carthamin-synthesizing enzyme) were done with a soluble extract of safflower seedlings. Ethanol and acetone seriously affected the solubility and the activity of the enzyme. Ammonium sulfate fractionation, calcium acetate precipitation and protamine sulfate treatment were all useful techniques for removing inert protein from the crude extract however, the activity of the carthamin-synthesizing enzyme could not be separated from that of native polyphenol oxidase or peroxidase. Partial purification of the carthamin-synthesizing enzyme could be achieved by filtration of a crude extract through Sephadex G-100 gel after treating it with ammonium sulfate, calcium acetate and protamine sulfate. The purified enzyme reacted possitively with precarthamin at $\mathrm{pH} 4.8$ in $50.0 \mathrm{mM}$ acetate buffer. The synthesized product was identified as carthamin by checking its $R_{f}$ values on silica gel plates developed with three different developing solvents and UV absorption spectral pattern in methanol. The enzyme sample was unstable on storage and stabilization of the sample was tested by applying many procedures. Carthamin-synthesizing enzyme had low affinity to celite 535. No carthamin was found in an incubation medium containing precarthamin and an authentic sample of polyphenol oxidase or peroxidase. Carthamin could not be converted to any blackish catabolites through polyphenol oxidase- or peroxidase-catalyzed oxidative reaction. Changes in the activities of three different enzymes, carthamin-synthesizing enzyme, polyphenol oxidase and peroxidase, were investigated in the extract from both etiolated and green seedlings of safflower and the data were discussed in relation to the catalytic properties of the enzymes.
\end{abstract}

Key words: Carthamus tinctorius, carthamin synthesis, enzyme isolation, enzyme property

\section{INTRODUCTION}

Carthamin, C-glucopyranosyl quinoidchalcone, is a Carthamus plant pigment. It accumulates in the floral tissues and contributes to reddening

* To whom all correspondence should be addressed. 
of the yellow tubular flowers. The process of the flower reddening has been supposed to be regulated by polyphenol oxidase- or peroxidase-catalyzed oxidation of a putative carthamin precursor, leucocarthamin (Shi m ok or i y a ma and Hattori 1955). In a recent series of experiments, we demonstrated that carthamin was synthesized from a flame-coloured precarthamin by cell-free extracts from mature flowers and etiolated seedlings of Carthamus tinctorius (Saito et al. 1983a, b, Takahashi et al. 1984). The synthetic reaction proceeded readily under aerobic rather than anaerobic conditions, which was confirmed by performing the enzyme reaction in an atmosphere of argon gas (Saito et al. $1983 \mathrm{a}$ ). The activity of the enzyme responsible for carthamin synthesis (carthamin-synthesizing enzyme) is detectable in all above-ground parts of the flowering plant, while cathamin and precarthamin occur in limited of the flower florets. The specific activity of the enzyme is high in younger developing tissues. This does not coincide with the stage of the flower reddening, which arieses at a relatively later phase of the blooming period. The calalytic activity of the enzyme is easily reduced by the presence of phosphate ions. This led as to wonder if carthamin is synthesized from precarthamin through the process of polyphenol oxidase- or peroxidase-catalyzed oxidation reaction. To clarify the synthetic mechanism of the red pigment, purification of the enzyme seems to be absolutely required.

In the following study, preparative operations were done for isolation of the carthamin-synthesizing enzyme from soluble extract of safflower seedlings. Some properties of the enzyme were also investigated with reference to the catalytic mechanism in flower reddening process.

\section{MATERIAL AND METHODS}

MATERIAL

The crude extract for isolation of carthamin-synthesizing enzyme was prepared from 3-4 day old seedling which were grown in a growth box at $27^{\circ} \mathrm{C}$ in darkness. Green seedlings were harvested from experimental planting pots kept in an open field. Precarthamin was prepared following the method described in our recent paper (Takahashi et al. 1984). 2-Mercaptoethanol was purchased from Kanto Chemical Co., Inc., (Tokyo, Japan). Dithiothreitol was obtained from Nakarai Kagaku Yakuhin Co., Ltd. (Kyoto, Japan), Sodium D-araboascorbate was product of Tokyo Kasei Kogyo Co., Ltd., (Tokyo, Japan). Sephadex G-25, G-100 and blue dextran were purchased from Pharmacia Fine Chemicals (Uppsala, Sweden). Protamine 
sulfate, mushroom tyrosinase and horseradish peroxidase were purchased from Sigma Chemical Co. (St. Louis, Mo. USA). Other chemicals were also from commercially available sources.

PREPARATION OF AN ENZYME EXTRACT

Seedlings with no roots were sterilized in $3.1 \mathrm{~cm}^{3} \cdot \mathrm{g}$ fresh weight ${ }^{-1}$ of $70 \%$ aqueous ethanol for $3 \mathrm{~min}$ and then washed 6 times with $4.7 \mathrm{~cm}^{3} \cdot \mathrm{g}$ fresh weight ${ }^{-1}$ of distilled water per washing. The washed materials were homogenized in a chilled Waring blender with ice-cold $50.0 \mathrm{mM}$ citrate-phosphate buffer, pH 7.0, containing $20.0 \mathrm{mM}$ sodium D-araboascorbate and $0.1 \mathrm{mM}$ 2-mercaptoethanol. The homogenate was squeezed through nylon-cloth and the filtrate was centrifuged at $15000 \times \mathrm{g}$ for $20 \mathrm{~min}$. The supernatant was fractionated with solid ammonium sulfate. The fraction precipitated between 40 and $80 \%$ ammonium sulfate saturation was collected, followed by treating successively with Sephadex G-25, calcium acetate $(0.5 \%, \mathrm{w} / \mathrm{v})$, protamine sulfate $(0.18 \%, \mathrm{w} / \mathrm{v})$ and Sephadex G-100 gel. The active fractions, obtained from the final Sephadex G-100 gel eluate, were used for enzyme assay. Protein content was determined by the reported method (Lowry et al. 1951).

The activity of carthamin-synthesizing enzyme was assayed spectrophotometrically by recording the optical density at $517 \mathrm{~nm}$ in the incubation mixture (Saito et al. $1983 \mathrm{a}, \mathrm{b}$ ) or in a $60 \%$ acetone eluate from cellulose powder with the reaction product. The activity of the enzyme was shown as the amount which catalyzed the formation of $1 \mu \mathrm{mol}$ carthamin $\cdot \mathrm{min}^{-1}$ under standard assay conditions and the specific activity was expressed as the activity $\cdot \mathrm{mg}_{\text {protein }}{ }^{-1}$. The activity of polyphenol oxidase was estimated with a Shimadzu spectrophotometer (type UV 150-02) by following changes in absorbance at $475 \mathrm{~nm}$ when L-3,4-dihydroxyphenylalanine was given as a substrate (Horowitz et al. 1970). Peroxidase activity was determined at $420 \mathrm{~nm}$ using guaiacol as the hydrogen doner (Tomi yama and Stahmann 1964).

VERIFICATION OF THE ENZYME PRODUCT

The incubation product was verified by its $\mathrm{Rf}$ values on chromatograms developed with three different solvents and UV absorption pattern in methanol. $\mathrm{R}_{f}$ values were measured on air dried silica gel thin-layer 
plates (E. Merck, Darmstadt, FRG) developed with 1-butanol/acetic acid /water (4:1:2, by vol.), phenol/acetic acid/water (40:1:10, by vol.) and ethyl acetate/pyridine/water (15:5:3, by vol.). Each solvent was run ascendingly at room temperature $(20-25 \mathrm{C})$. UV spectra were determined in methanol with a spectrophotometer (Shimadzu, type UV 150-02) at $517 \mathrm{~nm}$.

An aliquot of extract was freezed in a refrigerator at $-20 \mathrm{C}$ for $48 \mathrm{~h}$ and the freezed extract was dissolved in tap water at $7 \mathrm{C}$ for enzyme assay. Another aliquot was freeze-dried under reduced pressure with liquid nitrogen. The dried material was kept in a stocker at 2-4 C before use. Reducing agents (sodium L-ascorbate, sodium D-araboascorbate) and sulfhydryl compounds (2-mercaptoethanol, dithiothreitol) were added to reaction mixture at $0.1 \mathrm{mM}$ level prior to the initiation of the enzyme reaction. Standard assay was done on each sample for testing. The assay conditions are described above.

$10 \mu \mathrm{g}$ precarthamin was incubated at $30^{\circ} \mathrm{C}$ for $10 \mathrm{~min}$ in a reaction mixture containing 16,3 units mushroom tyrosinase (polyphenol oxidase, 2600 units $\cdot \mathrm{mg} \mathrm{solid}^{-1}$ ) and $50.0 \mathrm{mM}$ acetate buffer, $\mathrm{pH} 4.8$, or $50.0 \mathrm{mM}$ phosphate buffer, $\mathrm{pH} 6.7$, in a total volume of $5.5 \mathrm{~cm}^{3}$. Another $10 \mu \mathrm{g}$ precarthamin was added to 7.8 units horseradish peroxidase (265 purpurogallin units $\cdot \mathrm{mg} \mathrm{solid}^{-1}$ ) in an incubation system composed of $16.5 \mathrm{mM}$ hydrogen peroxidase, $50.0 \mathrm{mM}$ acetate buffer, $\mathrm{pH} 4.8$, or $50.0 \mathrm{mM}$ phosphate buffer, $\mathrm{pH} 6.0$, in a total volume of $4.5 \mathrm{~cm}^{3}$. The resulting products were examined under visible light and with a Shimadzu UV 150-02 spectrophotometer. At short intervals, the products of both polyphenol oxidase and peroxidase activities in the incubation systems were chacked spectrophotometrically at 475 or $420 \mathrm{~nm}$.

The chromatographically pure reaction product was incubated with mushroom tyrosinase or horseradish peroxidase in the following incubation systems. For polyphenol oxidase: $2.0 \mathrm{mg}$ reaction product, 16.3 units mushroom 
tyrosinase and $50.0 \mathrm{mM}$ phosphate buffer, in a final volume of $4.5 \mathrm{~cm}^{3}$. For peroxidase: $2.0 \mathrm{mg}$ reaction product, 7.8 units horseradish peroxidase, $16.5 \mathrm{mM}$ hydrogen peroxidase and $50.0 \mathrm{mM}$ phosphate buffer, ph 6.0 , in a final volume of $5.5 \mathrm{~cm}^{3}$. Control tests for assaying activities of polyphenol oxidase and peroxidase were also carried out in the following incubation systems. For polyphenol oxidase: $4.0 \mathrm{mM}$ L-3,4-dihydroxyphenylalanine, 16.3 units mushroom tyrosinase and $50.0 \mathrm{mM}$ phosphate buffer, $\mathrm{pH} 6.7$, in a final volume of $4.5 \mathrm{~cm}^{3}$. For peroxidase: $20.0 \mathrm{mM}$ guaiacol, $16.5 \mathrm{mM}$ hydrogen peroxidase, 7.8 units horseradish peroxidase and $50.0 \mathrm{mM}$ phosphate buffer, $\mathrm{pH} 6.0$, in a final volume of $5.5 \mathrm{~cm}^{3}$. Each reaction was done at $30 \mathrm{C}$ and, at intervals, the incubation medium was examined in visible light.

RESULTS

EFFECT OF POLAR AND NON-POLAR SOLVENTS ON THE ACTIVITY OF CARTHAMIN-SYNTHESIZING ENZYME

Non-polar solvents are often used to obtain enzyme extract as dried powder. In this experiment we have tested acetone and ethanol as the solvents for isolation and separation of carthamine-synthesizing enzyme. However, the resulting powdered preparations were found to keep only little or no activity of the enzyme compared with that of intact crude extract. These organic solvents cause a reduction in the solubility of the enzyme protein. Although the salting-out method using ammonium sulfate was a useful technique for removing inactive protein from the extract, separation of the activities of three enzymes, carthamin-synthesizing enzyme, polyphenol oxidase and peroxidase, could not be achieved by this procesure (Fig. 1). Calcium acetate, protamine sulfate, acetone and ethanol were also of little use to this purpose. Carthamin-synthesizing enzyme was separated by using Sephadex G-100 gel, though only partially (Fig. 2).

VERIFICATION OF THE ENZYME PRODUCT

$\mathrm{R}_{f}$ values of the enzyme product in three different solvents were the same as those of an authentic carthamin. UV spectra of the chromatographically pure product and an authentic sample in methanol were $(\mathrm{nm}): 210,250$ (inflex.), 310 (inflex.), 370 and 517. 


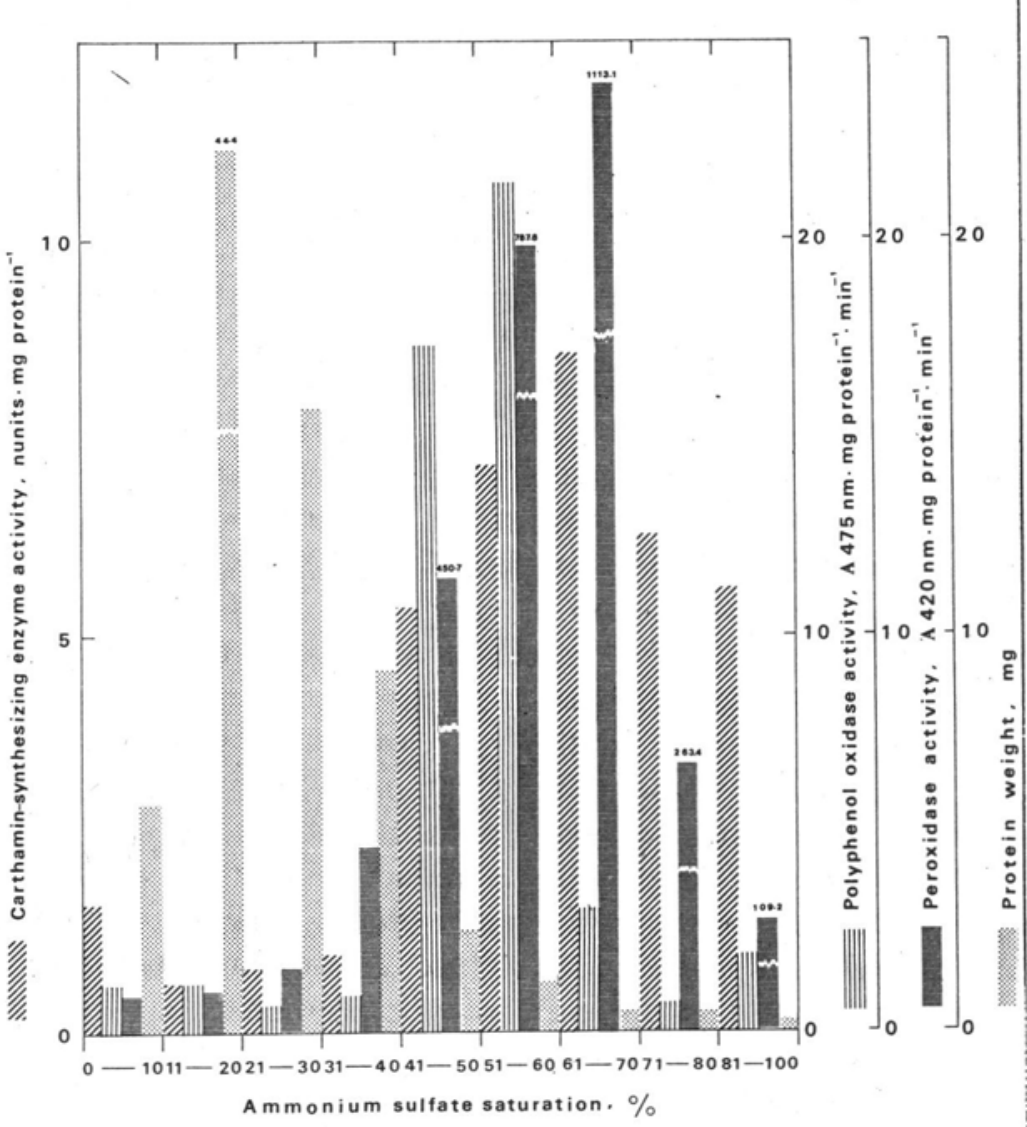

Fig. 1. Fractionation of a crude extract from safflower seedlings with solid ammonium sulfate. Etiolated seedlings were homogenized in cold extraction medium. The supernatant obtained by centrifugation at $15000 \times \mathrm{g}$ for $20 \mathrm{~min}$ was fractionated with various concetrations of ammonium sulfate as indicated in the figure. The pellet was passed through Sephadex G-25 and resulting salt-free protein fractions were used for enzyme assays. The activity of carthamin-synthesizing enzyme was measured under the standard assay conditions as described in Material and Methods. Polyphenol oxidase activity was estimated spectrophotometrically according to Horowitz et al. (1970) in a reaction mixture, consisting of 0.032-0.68 mg enzyme protein and 4.0 mM L-3,4-dihydroxyphenylalanine in $50.0 \mathrm{mM}$ phosphate buffer, $\mathrm{pH} 6.7$, in a final volume of $3.5 \mathrm{~cm}^{3}$. The colour change, manifested by increasing absorbance at $475 \mathrm{~nm}$, was recorded at $30^{\circ} \mathrm{C}$ for $5 \mathrm{~min}$. The activity of peroxidase was assayed a spectrophotometrically by recording the change in optical density at $420 \mathrm{~nm}$ within $5^{\circ} \mathrm{min}$ at $30^{\circ} \mathrm{C}$. The reaction mixture contained following components in a total volume of $4.0 \mathrm{~cm}^{3}: 0.032-0.68 \mathrm{mg}$ enzyme extract, $20.0 \mathrm{mM}$ guaiacol, $16.5 \mathrm{mM}$ hydrogen peroxide, $50.0 \mathrm{mM}$ phosphate buffer, $\mathrm{pH} 6.0$ 
Optimal $\mathrm{pH}$ for carthamin synthesis directed by carthamin-synthesizing enzyme was at 4.8 in $50.0 \mathrm{mM}$ acetate buffer (Fig. 3). the value of which is lower than that previously observed (Saito et al. $1983 \mathrm{a}$, b). Carthamin-synthesizing enzyme showed to be less adsorptive to celite 535 (Fig. 4). The enzyme is unstable on storage (Fig. 5). Only a little stabilization could be preserved by freezing and freeze-drying of the sample or by the addition of reducing agents and sulfhydrol compounds to the enzyme sample.

COMPARISON OF THE CATALYTIC PROPERTIES OF CARTHAMIN-SYNHESIZING ENZYME WITH THOSE OF POLYPHENOL OXIDASE AND PEROXIDASE

To compare the properties of three enzymes, carthamin-synthesizing enzyme, polyphenol oxidase and peroxidase, we tested the time dependence of the catalytic activity change in extracts from etiolated and green seedlings.

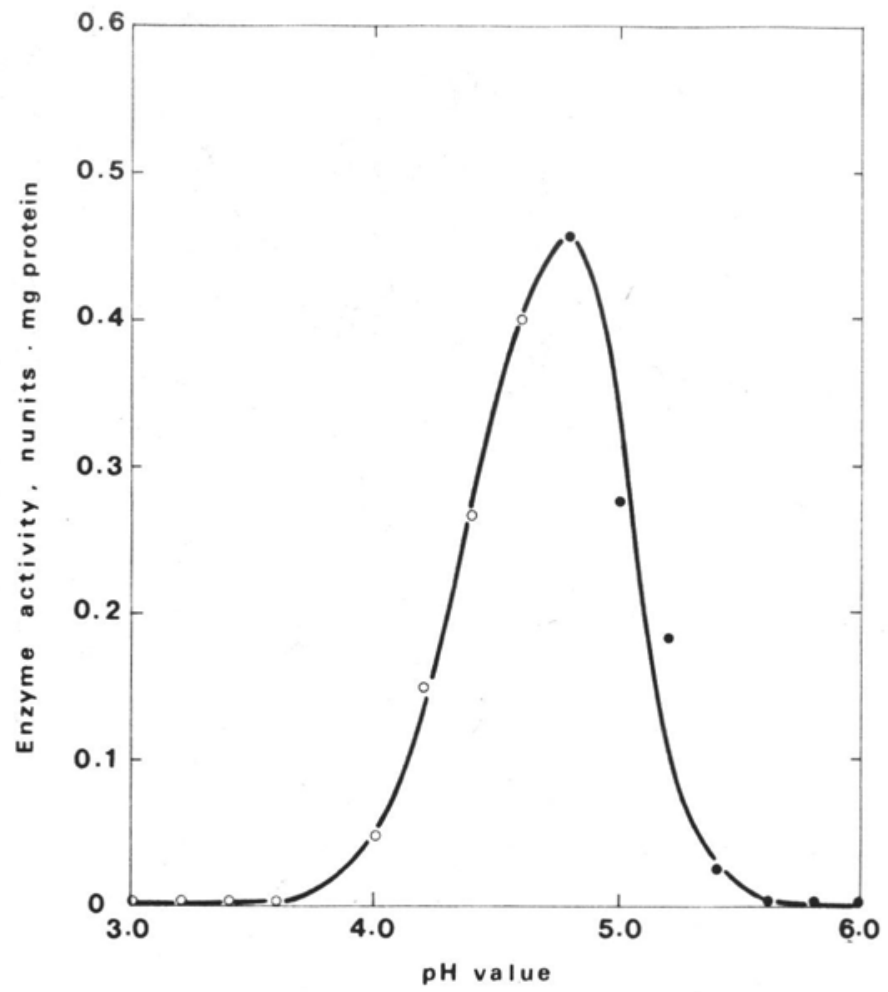

Fig. 3. Effect of $\mathrm{pH}$ value on the enzymic synthesis of carthamin. Enzyme assays were carried out as described in Material and Methods except that buffers used in the reaction mixtured were varied as shown: (○) $50.0 \mathrm{mM}$ citrate buffer; (๑) $50.0 \mathrm{mM}$ acetate buffer 


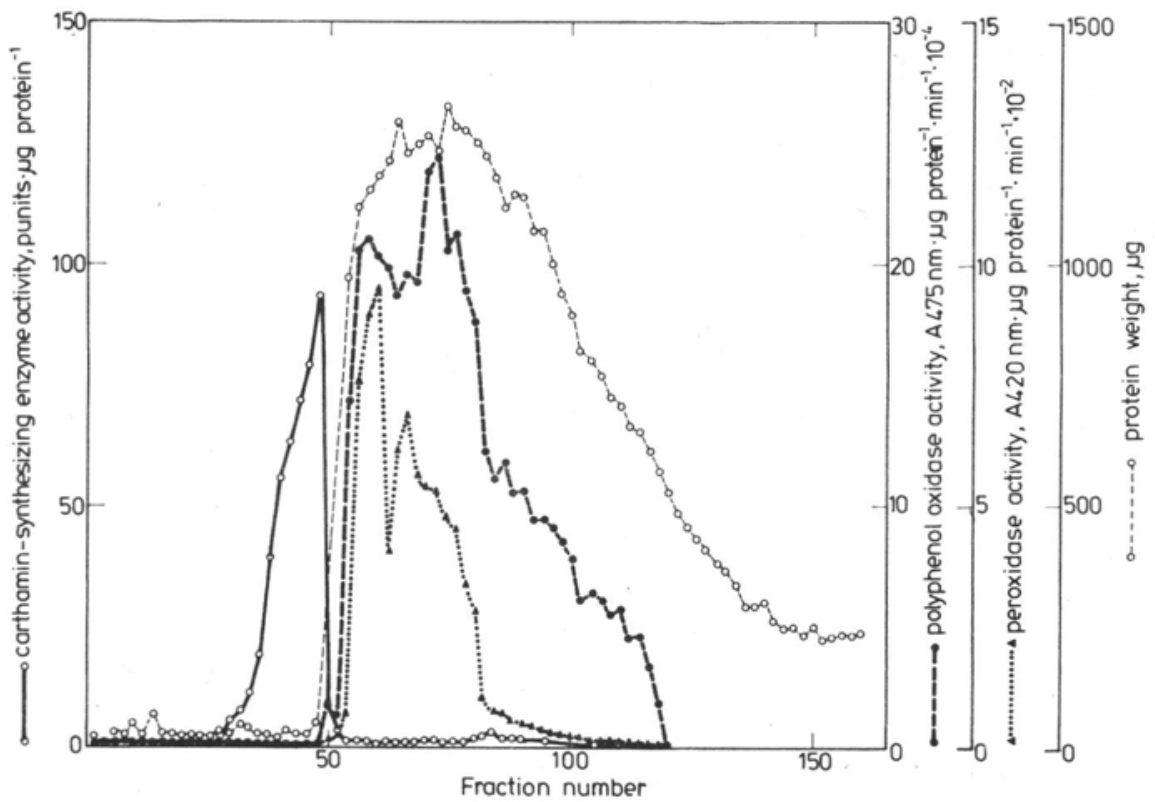

Fig. 4. Comparison of the adsorptive properties on carthamin-synthesizing enzyme polyphenol oxidase and peroxidase to celite 535. The salt-free protein solution after treating the crude homogenate sucessively with ammonium sulfate, calcium acetate and protamin sulfate was passed through a column $(2.4 \times 70 \mathrm{~cm})$ of celite 535 which had been previously equilibrated with $5.0 \mathrm{mM}$ citrate-phosphate buffer, $\mathrm{pH}$ 7.0, and the adsorbed protein was eluted by gravity flow with the same buffer. The activities of carthamin-synthesizing enzyme. polyphenol oxidase and peroxidase were determined as shown in Material and Methods, and Fig. 1

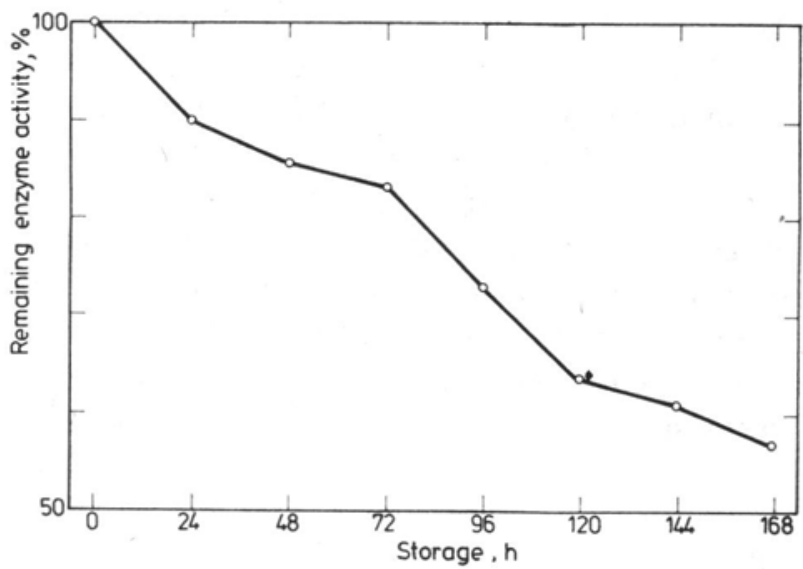

Fig. 5. Stability of carthamin-synthesizing enzyme. The enzyme solution was kept in a stocker at 2-4 C. At the required time for testing, an aliquot of the solution was pipetted out to examine the remaining activity of carthamin-synthesizing enzyme. The enzyme assay was done under the standard assay conditions as presented in Material and Methods 


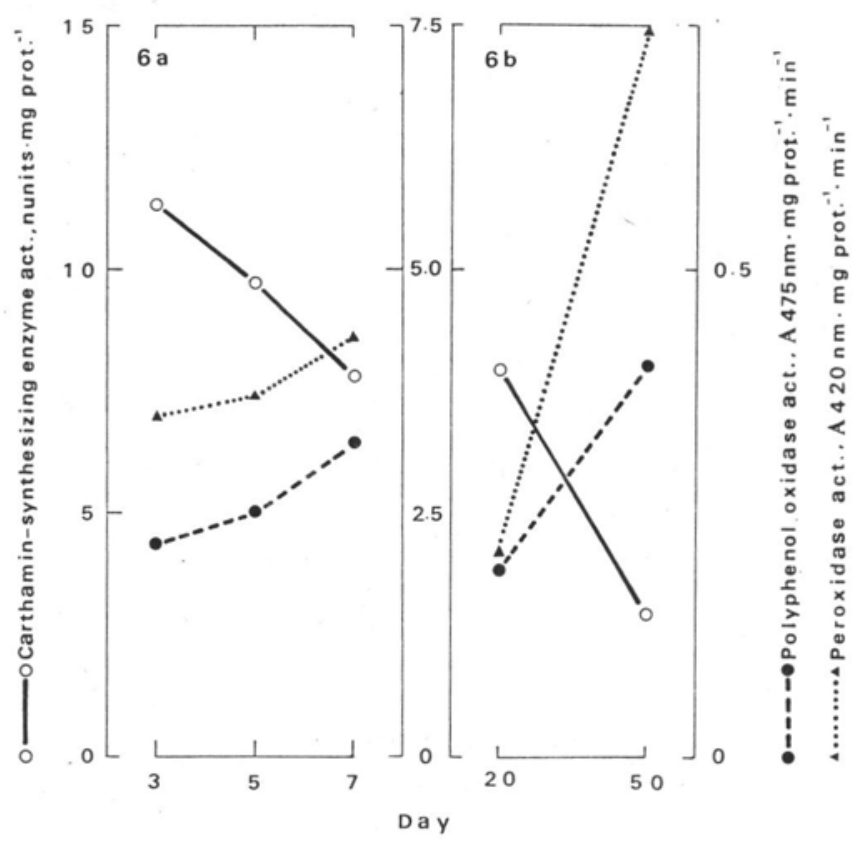

Fig. 6. Time dependence of the catalytic activity change of carthamin-synthesizing enzyme, polyphenol oxidase and peroxidase in tissue ageing. Enzyme activity change in etiolated seedlings (6a). Enzyme activity change in green seedlings (6B). Carthamin-synthesizing enzyme activity was determined by a conventional method (Takahashi et al. 1984) with some minor modifications. The activities of polyphenol oxidase and peroxidase were assayed as described in the text

The results were illustrated in Figs. $6 \mathrm{a}$ and $6 \mathrm{~b}$. In both etiolated and green seedlings, carthamin-synthesizing enzyme always kept a high activity in the younger tissues. This matches partly with our previous results (Saito et al. $1983 \mathrm{a}, \mathrm{b})$. No carthamin was synthesized in a reaction mixture containing precarthamin and polyphenol oxidase or peroxidase (Fig. 7). The redish enzyme product, which was identified as carthamin, was incubated in a buffer solution with mushroom tyrosinase or horseradish peroxidase, however, it was only turned to unknown orange or redish orange catabolites and could not be converted to any blackish products, which are usually detectable in an reaction system with L-3,4-dihydroxyphenylalanine and mushroom tyrosinase or with guaiacol, hydrogen peroxidase and peroxidase (Table 1).

\section{DISCUSSION}

Carthamin is synthesized from precarthamin through an enzyme mediating an oxygenative reaction, the fact of which we have already shown at 
a cell-free level using soluble extracts from matured and young safflower tissues (Saito et al. $1983 \mathrm{a}, \mathrm{b}, \mathrm{T}$ akahashi et al. 1984). In this work, several procedures were tested for isolation and separation of an enzyme associated with the carthamin synthesis (carthamin-synthesizing enzyme) from the extract of etiolated hypocotyls of safflower seedlings. Treating

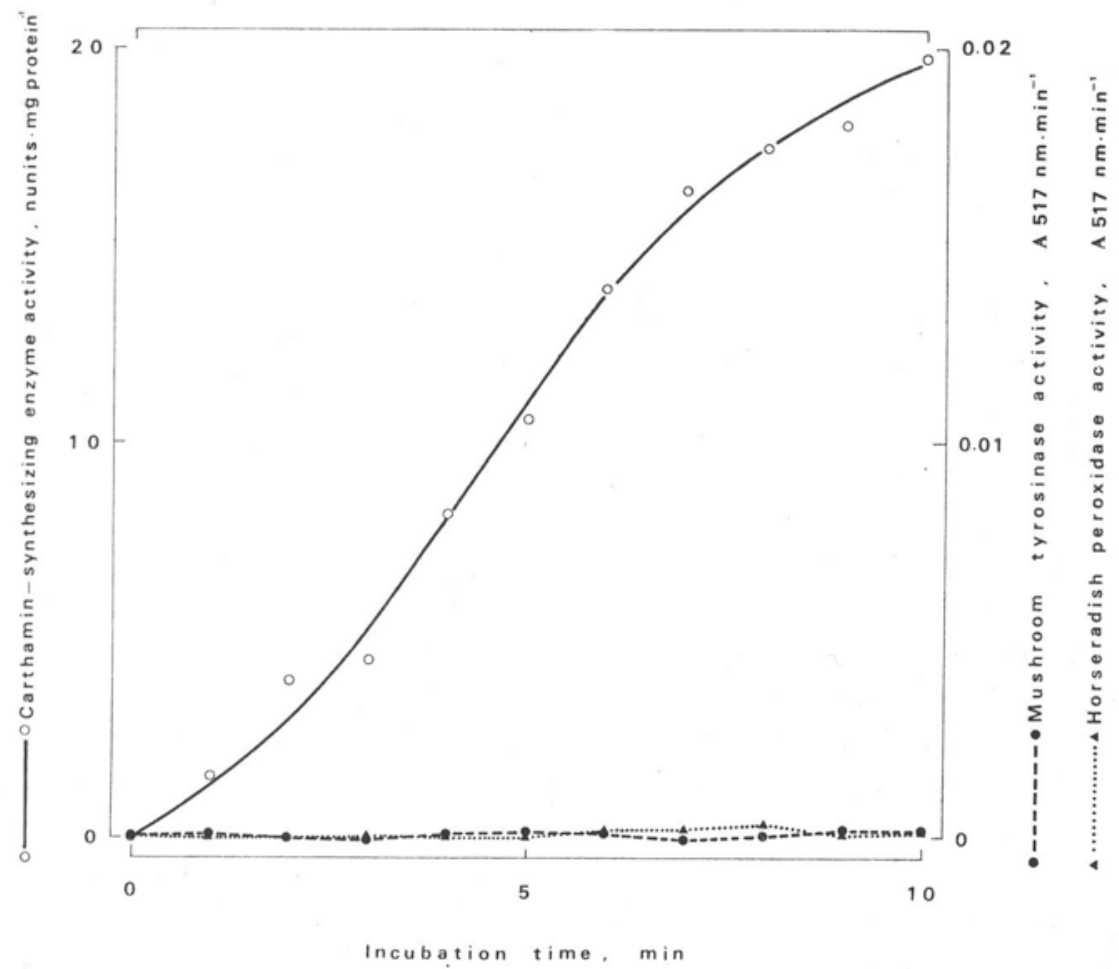

Fig. 7. Reactivity of carthamin-synthesizing enzyme, mushroom tyrosinase and horseradish peroxidase with precarthamin. $0.64-1.35 \mathrm{mg}$ enzyme protein from etiolated safflower seedlings were incubated in $2.5 \mathrm{~cm}^{3}$ of $50.0 \mathrm{mM}$ acetate buffer, $\mathrm{pH} 4.8$, containing $0.44 \mu \mathrm{g}$ precarthamin at $30 \mathrm{C}$. The activity of the enzyme was measured as shown in the above section. Composition of the reaction mixture and conditions for assaying mushroom tyrosinase and horseradish peroxidase are presented in the text

the crude extract with ammonium sulfate, calcium acetate and protamine sulfate was a very useful technique for excluding inert protein from the extract, however, no activity of carthamin-synthesizing enzyme could be separated from that of polyphenol oxidase or peroxidase. Partial purification of the carthamin-synthesizing enzyme was achieved by gel filtration through Sephadex G-100. The purified enzyme reacted at $\mathrm{pH} 4.8$ in $50.0 \mathrm{mM}$ acetate buffer with added precarthamin to produce a red product, which was 
Table 1

Time dependence of colour change in the reaction mixture containing carthamin and mushroom tyrosinase or carthamin and horseradish peroxidase

\begin{tabular}{|c|c|c|c|c|}
\hline $\begin{array}{l}\text { Incubation } \\
\text { time, min }\end{array}$ & $\begin{array}{c}\text { Tyrosinase, } \\
\text { control }\end{array}$ & $\begin{array}{l}\text { Tyrosinase, used } \\
\text { with carthamin }\end{array}$ & $\begin{array}{c}\text { Peroxidase, } \\
\text { control }\end{array}$ & $\begin{array}{l}\text { Peroxidase, used } \\
\text { with carthamin }\end{array}$ \\
\hline 0 & yellow & red & yellow & red \\
\hline 10 & yellowish brown & reddish orange & red & reddish orange \\
\hline 20 & reddish brown & reddish orange & light orange brown & reddish orange \\
\hline 30 & $\begin{array}{c}\text { dark reddish } \\
\text { brown }\end{array}$ & reddish orange & orange brown & reddish orange \\
\hline 40 & black & reddish orange & reddish brown & orange \\
\hline 50 & black & reddish orange & $\begin{array}{l}\text { dark reddish } \\
\text { brown }\end{array}$ & orange \\
\hline 60 & black & reddish orange & $\begin{array}{l}\text { dark reddish } \\
\text { brown }\end{array}$ & orange \\
\hline 90 & black & $\begin{array}{l}\text { light reddish } \\
\text { orange }\end{array}$ & blackish brown & orange \\
\hline 120 & black & orange & blackish brown & orange \\
\hline
\end{tabular}

Composition of the incubation mixture and condition for the enzyme assay are described in the text

finally identified as carthamin by checking its chromatographic mobilities in different solvents and spectral pattern in methanol. Instability of the enzyme did not allow us to store the sample at the fully active state. The addition of reducing agents or sulfhydryl compounds to the sample storage vessel was ineffective. Dried powder of the enzyme protein prepared with cold ethanol and acetone or by freeze-drying was found to keep only little or no activity of the enzyme for carthamin synthesis. This may reflect the fact that the enzyme could be seriously denatured during the process of dry powder preparation, because a considerable decrease in the solubility of the powdered samples was observed. No effective procedures for stabilization of the sensitive protein were found in this study.

In our preceding studies we noticed that carthamin formation at a cell-free level was readily affected by the presence of phosphate ions (Saito et al. $1983 \mathrm{a}, \mathrm{b})$. The results let us suppose that carthamine-synthesizing enzyme might differ from polyphenol oxidase and peroxidase. Evidence from the present study supports our previous supposition: 1) the activity of cathamin-synthesizing enzyme is preferably high in younger tissues, while that of polyphenol oxidase or peroxidase tends to increase gradually with tissue elongation; 2) carthamin-synthesizing enzyme is less adsorptive to celite 535, which has been known to be a specific binder to copper proteins (Fling et al. 1963, Katan and Galun 1975); 3) the activity of carthamin-synthesizing enzyme is separable from that of polyphenol oxidase or peroxidase on Sephadex G-100 gel; 4) no carthamin is formed from precarthamin by 
incubation with an authentic sample of polyphenol oxidase or peroxidase; 5) carthamin can never be converted further to any blackish catabolites through polyphenol oxidase- or peroxidase-catalyzed oxidation reaction. Carthamin is composed of a specific chalcone structure with no O-dihydroxyls on the mother skeleton, the fact of which reflect on the resistance to the catalytic activities of these two polyphenol oxidizing enzymes.

In 1955, Shimokoriyama and Hattori proposed a mechanism for the flower reddening process, supposing that an oxidative reaction catalyzed by polyphenol oxidase or peroxidase might be involved in the flower colour transition response (Shimokoriyama and Hattori 1955). However, their data seem to have some inevitable weak points. The reasons are as follows: 1) hydrogen peroxidase which was used as a hydrogen acceptor might serve as an oxidizing reagent in the reaction system to produce a red substance, presumably carthamin (Saito and Takahashi 1985); 2) the activity of carthamin-synthesizing enzyme is always detectable contamined with that of polyphenol oxidase or peroxidase in the flower extract, including dried ethanol powder; 3) precarthamin can be converted to certhamin through an auto-oxidation reaction (Saito and Takahashi 1985). In this study we could not obtain any positive evidence to uphold the suppositional mechanism of Shomokoriyama and Hattori (1955). The response of the floret reddening in safflower may be controlled by an oxidazing enzyme different from polyphenol oxidase and peroxidase.

To reveal the mechanism of the flower colour transit reaction, purification of the carthamin-synthesizing enzyme is indispensable. Work on isolation, purification and stabilization of the enzyme is underway in our laboratories.

\section{REFERENCES}

Horowitz N. H., Fling M., Horn G., 1970. Tyrosinase (Neurospora crassa). In: Methods in enzymology. Tabor H., Tabor C. W. (eds.). Academic Press, New York, 17A: pp. 615-620.

Fling M., Horowitz N.H., Heinemann S. F., 1963. The isolation and properties of crystalline tyrosinase from Neurospora. J. Biol. Chem. 238: 2045-2053.

Katan T., Galun E., 1975. A rapid and efficient method for the purification of tyrosinase from Neurospora. Analyt. Biochem. 67: 485-492.

Lowry O. H.. Rosebrough N. J.. Farr A. L.. Randall R. J., 1951. Protein measurement with Folin phenol reagent. J. Biol. Chem. 193: 265-275.

Saito K., Takahashi Y., Wada M., 1983 a. Enzymic synthesis of carthamin in sufflower. Biochim. Biophys. Acta 756: 217-222.

Saito K., Takahashi Y., Wada M., 1983 b. Distribution and variation of the catalytic activity of the enzyme responsible for carthamin synthesis in safflower seedlings. Z. Naturforsch. 38 c: 724-729.

Saito K., Takahashi Y.. 1985. Studies on the formation of carthamin in buffer solutions containing precarthamin and oxidizing agents. Acta Soc. Bot. Pol. 54: 231-240. 
Shimokoriyama M.. Hattori S.. 1955. On the formation of carthamin in the flowers of Carthamus tinctorius. Arch. Biochem. Biophys. 54: 93-101.

Takahashi Y., Wada M., Saito K., 1984. Purification and some characteristics of precarthamin, a precursor of carthamin, isolated from the florets of Carthamus tinctorius L. Acta Soc. Bot. Pol. 53: 187-198.

Tomiyama K., Stahmann M.A.. 1964. Alteration of oxidative enzymes in potato tuber tissue by infection with phytophthora infestans. Plant Physiol. 39: 483-490.

\section{Wstepne badania nad izolacjq enzymu zwiazanego z synteza kartaminy $u$ Carthamus tinctorius $L$.}

\section{Streszczenie}

Rozpuszczalny ekstrakt siewek krokosza użyto do wstępnych czynności związanych z izolacią enzymu biorącego udział w syntezie kartaminy (enzymu syntezującego kartaminę). Etanol i aceton wyraźnie wpływały na rozpuszczalność i aktywność badanego enzymu. Frakcjonowanie siarczanem amonu, strącanie actanem wapnia i traktowanie siarczanem protaminy okazały się przydatnymi technikami do usuwania inertnego białka $\mathrm{z}$ surowego akstraktu, pomimo. że nie udało się oddzielić aktywności enzymu syntezuiącego kartaminę od aktywności naturalnei polifenolowej oksydazy i peroksydazy. Czẹściowe oczyszczenie enzymu syntezuiącego kartaminę można osiągnąć dzięki fillıracji surowego ekstraktu na żelu Sephadex G-100, po uprzednim potraktowaniu ekstraktu siarczanem amonu. octanem wapnia i siarczanem protaminy. Oczyszczony enzym reagował z prekartaminą w $50.0 \mathrm{mM}$ buforze octanowym przy pH 4.8. Zsyntezowany produkt zidentyfikowano jako kartaminę przez określenie wartości $\mathbf{R}_{f}$ po elektroforezie na płytkach z żelem krzemionkowym. przy użyciu trzech różnych systemów rozwijających oraz przez określenie wzoru absorpcji spektralnei w UV w metanolu. Próbka enzymu okazała się nietrwała w przechowywaniu, dlatego użyto kilku sposobów w celu jej stabilizacji. Enzym syntezujący kartaminę wykazywał małe powinowactwo do celitu 535. Nie znaleziono kartaminy w płynie inkubacyjnym, zawierającym prekartaminę i oryginalną próbkę polifenolowej oksydazy lub peroksydazy. Nie udało się przemienić kartaminy w żaden z czarnych katabolitów w reakcii utleniającej, katalizowanej przez polifenolową oksydazę lub peroksydazę. W ekstraktach zarówno etiolowanych, jak i zielonych siewek krokosza badano zmiany aktywności trzech różnych enzymów (enzymu syntezującego kartaminę. polifenolowej oksydazy i peroksydazy); wyniki przedyskutowano pod kątem własności katalitycznych tych enzymów. 